\title{
(2) Genetic and Some Environmental Factors Concerning with Development of Autoimmune Diseases, with Special Reference to Autoimmune Hapatitis
}

\author{
Kenichi Ito, Tokugoro Tsunematsu, Chisato Minaguchi \\ and Yoshiro TAMAI \\ Department of Internal Medicine, Faculty of Medicine, Kyoto University
}

From the family studies of 6 patients with autoimmune hepatitis (active chronic hepatitis, lupoid type), it has been demonstrated that serological abnormalities in immunoglobulin levels and incidence of humoral auto-antibodies such as anti-liver, anti-smooth muscle, anti-thyroid and anti-nuclear antibodies were frequently encountered in the family members of these patients. Occurrence of ANF and thyroid antibody seemed to be preferable in the female members (Table 1). Among the relatives of the patients with autoimmune hepatitis, an increased incidence of other autoimmune diseases, e.g. chronic thyroiditis, RA and Behçet's disease, as well as chronic hepatitis with abnormal immunological features has been observed.

Table 1. Family Studies on Autoimmune Hepatitis - Serological-

\begin{tabular}{|c|c|c|c|c|c|c|c|c|c|}
\hline \multirow{2}{*}{$\begin{array}{c}\text { Number } \\
\text { of } \\
\text { propositus }\end{array}$} & $\begin{array}{c}\text { Number } \\
\text { of } \\
\text { Relatives }\end{array}$ & $\begin{array}{c}\text { Hyper } \\
\gamma \text {-glob }\end{array}$ & $\operatorname{IgG}$ & $\operatorname{IgA}$ & IgM & $\begin{array}{c}\text { Anti- } \\
\text { liver }\end{array}$ & $\begin{array}{l}\text { Anti- } \\
\text { smooth } \\
\text { muscle }\end{array}$ & ANF & $\begin{array}{c}\text { Anti- } \\
\text { thyroid }\end{array}$ \\
\cline { 3 - 10 } & $\begin{array}{c}14 \\
\text { males }\end{array}$ & $6 / 12$ & $6 / 13$ & $1 / 13$ & $4 / 13$ & $8 / 13$ & $2 / 13$ & $1 / 13$ & $4 / 13$ \\
\cline { 2 - 10 } & $\begin{array}{c}18 \\
\text { females }\end{array}$ & $9 / 18$ & $6 / 15$ & $2 / 15$ & $8 / 15$ & $7 / 15$ & $3 / 17$ & $5 / 18$ & $9 / 18$ \\
\hline
\end{tabular}

Fig. 1 shows a representative family, in which not only abnormal levels of IgG, IgA and IgM but also various circulating autoantibodies are found among the members thru 3 generations.

No abnormalities in cellular immunity were encountered in 4 relatives, as evaluated by macrophage migration inhibitory factor to liver homogenate and DNA. From above, it could be concluded that genetic predisposition to autoimmune reactions seemed to be inherited in autosomal dominant fashion. From the family studies on 13 patients with SLE, similar findings in serological abnormalities and modes of inheritance observed in autoimmune hepatitis have been obtained even in SLE (Table 2).

The above abnormal immunological events would be controled genetically and also based on the deranged immunological survaillance. 
We reported previously 12 cases of autoimmune hepatitis associated with chronic thyroiditis and found abnormal immunological predisposition observed in some families of the patients. Reuber and Glover reported that chronic thyroiditis probably due to immune mechanism and liver cirrhosis developed in Buffalo strain rats by the administration of $\mathrm{CCl}_{4}$. In our animal experiments, we have not observed chronic thyroiditis at all in control rats including Wistar, Sprague-Dowrey and Donryu strain rats, although the incidence of chronic thyroiditis in Buffalo strain rats was frequent. These experimental findings indicate that genetic factor would be one of very important factors concerning with development of the autoimmune disease.

Since Australia antigenemia and cellular antibody to the antigen were not detected in a majority of the patients with autoimmune hepatitis, Australia antigen itself seems to be little related to persistence of autoimmune mechanism.

Table 2. Family Studies on SLE --Serological-

\begin{tabular}{|c|c|c|c|c|c|c|c|c|c|}
\hline \multirow{2}{*}{$\begin{array}{c}\text { No.of } \\
\text { Propositus }\end{array}$} & $\begin{array}{c}\text { No.of } \\
\text { Relatives }\end{array}$ & $\begin{array}{c}\text { Hyper- } \\
\gamma \text {-Gl }\end{array}$ & Ig G & Ig A & Ig M & ANF & RAT & $\begin{array}{c}\text { Anti- } \\
\text { TG }\end{array}$ & $\begin{array}{c}\text { Anti- } \\
\text { MS }\end{array}$ \\
\hline \multirow{3}{*}{13} & $\begin{array}{c}21 \\
\text { males }\end{array}$ & $4 / 21$ & $9 / 21$ & $2 / 21$ & $4 / 21$ & $1 / 21$ & $1 / 21$ & $1 / 21$ & $5 / 21$ \\
\cline { 2 - 10 } & $\begin{array}{c}27 \\
\text { females }\end{array}$ & $9 / 27$ & $7 / 27$ & $10 / 27$ & $12 / 27$ & $4 / 27$ & $2 / 27$ & $6 / 27$ & $12 / 27$ \\
\hline
\end{tabular}

